\author{
M.B. Muratbekov ${ }^{1, *}$, A.O. Suleimbekova ${ }^{2}$ \\ ${ }^{1}$ Taraz Regional University named after M.Kh. Dulaty, Taraz, Kazakhstan; \\ ${ }^{2}$ L.N. Gumilyev Eurasian National University, Nur-Sultan, Kazakhstan \\ (E-mail: musahan_m@mail.ru, suleimbekovaa@mail.ru)
}

\title{
On the existence of the resolvent and separability of a class of the Korteweg-de Vriese type linear singular operators
}

\begin{abstract}
Partial differential equations of the third order are the basis of mathematical models of many phenomena and processes, such as the phenomenon of energy transfer of hydrolysis of adenosine triphosphate molecules along protein molecules in the form of solitary waves, i.e. solitons, the process of transferring soil moisture in the aeration zone, taking into account its movement against the moisture potential. In particular, this class includes the nonlinear Korteweg-de Vries equation, which is the main equation of modern mathematical physics. It is known that various problems have been studied for the Korteweg-de Vries equation and many fundamental results obtained. In this paper, issues about the existence of a resolvent and separability (maximum smoothness of solutions) of a class of linear singular operators of the Korteweg-de Vries type in the case of an unbounded domain with strongly increasing coefficients are investigated.
\end{abstract}

Keywords: resolvent, Korteweg-de Vries type singular operator, separability.

\section{Introduction}

The solvability of boundary value problems for odd order differential equations, in particular, to the Korteweg-de Vries equation is dealt with in a significant literature [1-9] and the papers cited there.

In contrast to these interesting papers, this article deals with the problem of the existence of a resolvent and the separability of a class of linear singular operators of the Korteweg-de Vries type in the case of an unbounded domain with strongly increasing coefficients.

Note that if the boundary regime operates sufficiently long, then due to the friction inherent in any real physical system, the influence of the initial data weakens with time. Thus, we arrive at a problem without initial conditions [10].

Therefore, taking this remark into account in the present work, we consider the differential operator

$$
L u+\lambda u=\frac{\partial u}{\partial y}+R_{2}(y) \frac{\partial^{3} u}{\partial x^{3}}+R_{1}(y) \frac{\partial u}{\partial x}+R_{0}(y) u+\lambda u
$$

initially defined on $C_{0, \pi}^{\infty}(\bar{\Omega})$, where $\bar{\Omega}=\{(x, y):-\pi \leq x \leq \pi,-\infty<y<\infty\}, \lambda \geq 0$.

$C_{0, \pi}^{\infty}$ is a set of infinitely differentiable functions satisfying the conditions:

$$
u_{x}^{(i)}(-\pi, y)=u_{x}^{(i)}(\pi, y), \quad i=0,1,2
$$

and compactly supported with respect to the variable $y$.

Further assume that the coefficients $R_{0}(y), R_{1}(y), R_{2}(y)$ satisfy the following conditions:

i) $\left.R_{0}(y) \geq \delta_{0}\right)>0, R_{1}(y) \geq \delta_{1}>0,-R_{2}(y) \geq \delta_{2}>0$ are continuous functions in $R(-\infty,+\infty)$;

ii) $\mu_{0}=\sup _{|y-t| \leq 1} \frac{R_{0}(y)}{R_{0}(t)}<\infty, \mu_{1}=\sup _{|y-t| \leq 1} \frac{R_{1}(y)}{R_{1}(t)}<\infty, \mu_{2}=\sup _{|y-t| \leq 1} \frac{R_{2}(y)}{R_{2}(t)}<\infty$.

The operator $L+\lambda I$ admits closure in $L_{2}(\Omega)$, which we also denote by $L+\lambda I$.

Theorem 1. Let the condition i) be fulfilled. Then the operator $L+\lambda I$ is continuously invertible in $L_{2}(\Omega)$ for $\lambda \geq 0$.

\footnotetext{
${ }^{*}$ Corresponding author.

E-mail: musahan_m@mail.ru
} 
Definition. We called the operator $L$ is separable in $u \in D(L)$ if the estimate

$$
\left\|\frac{\partial u}{\partial y}\right\|_{L_{2}(\Omega)}+\left\|R_{2}(y) \frac{\partial^{3} u}{\partial x^{3}}\right\|_{L_{2}(\Omega)}+\left\|R_{1}(y) \frac{\partial u}{\partial x}\right\|_{L_{2}(\Omega)}+\left\|R_{0}(y) u\right\|_{L_{2}(\Omega)} \leq C\left(\|L u\|_{2}+\|u\|_{L_{2}(\Omega)}\right),
$$

holds for $u(x, y)$, where $\mathrm{C}$ is independent of $u(x, y),\|\cdot\|_{2}$ is the norm of $L_{2}(\Omega)$.

Theorem 2. Let conditions i) - ii) be fulfilled. Then the operator $L$ is separable.

Example. Let $R_{0}(y)=|y|+1, R_{1}(y)=e^{|y|}, R_{2}(y)=-10 \cdot e^{|y|},-\infty<y<\infty$. It is easy to verify that all the conditions of Theorem 2 are satisfied. Consequently, the operator $L$ is separable, i.e.

$$
\left\|\frac{\partial u}{\partial y}\right\|_{L_{2}(\Omega)}+\left\|10 \cdot e^{|y|} \frac{\partial^{3} u}{\partial x^{3}}\right\|_{L_{2}(\Omega)}+\left\|e^{|y|} \frac{\partial u}{\partial x}\right\|_{L_{2}(\Omega)}+\|(|y|+1) u\|_{L_{2}(\Omega)} \leq C\left(\|L u\|_{L_{2}(\Omega)}+\|u\|_{L_{2}(\Omega)}\right),
$$

$C$ is a constant.

\section{Auxiliary lemmas and inequalities}

Lemma 2.1. Let the condition i) be fulfilled and $\lambda \geq 0$. Then the inequality

$$
\|(L+\lambda I) u\|_{L_{2}(\Omega)} \geq\left(\delta_{0}+\lambda\right)\|u\|_{L_{2}(\Omega)},
$$

holds for all $u \in D(L)$, where $\delta_{0}>0$.

Proof. Let $u \in C_{0, \pi}^{\infty}(\bar{\Omega})$ and consider the scalar product

$$
\begin{gathered}
<(L+\lambda I) u, u>=\int_{\Omega}\left(\frac{\partial u}{\partial y}+R_{2}(y) \frac{\partial^{3} u}{\partial x^{3}}+R_{1}(y) \frac{\partial u}{\partial x}+\left(R_{0}(y)+\lambda\right) u\right) u d x d y= \\
=\int_{\Omega} \frac{\partial u}{\partial y} u d x d y+\int_{\Omega} R_{2}(y) \frac{\partial^{3} u}{\partial x^{3}} u d x d y+\int_{\Omega} R_{1}(y) \frac{\partial u}{\partial x} u d x d y+\int_{\Omega}\left(R_{0}(y)+\lambda\right) u^{2} d x d y .
\end{gathered}
$$

Since $u \in C_{0, p i}^{\infty}(\Omega)$ and (2) holds, then the following equalities:

$$
\int_{\Omega} \frac{\partial u}{\partial y} u d x d y=0 ; \quad \int_{\Omega} R_{1}(y) \frac{\partial u}{\partial x} u d x d y=0 ; \quad \int_{\Omega} R_{2}(y) \frac{\partial^{3} u}{\partial x^{3}} u d x d y=0 .
$$

hold. Using the equality (5) from (4) we have

$$
<(L+\lambda I) u, u>=\int_{\Omega}\left(R_{0}(y)+\lambda\right) u^{2} d x d y .
$$

From (6), using the Cauchy-Bunyakovsky inequality and the condition i), we obtain

$$
\|(L+\lambda I) u\|_{L_{2}(\Omega)} \geq\left(\delta_{0}+\lambda\right)\|u\|_{L_{2}(\Omega)},
$$

for all $u \in C_{0, \pi}^{\infty}(\bar{\Omega})$. By virtue of the continuity of the norm, the last estimate holds for all $u \in D(L)$. Lemma 2.1 is proved.

Remark. Due to the realness of the coefficients of (1) the estimate (7) holds for complex-valued functions. Consider the operator

$$
\left(l_{n, j}+\lambda I\right) z=z^{\prime}(y)+\left(-i n^{3} R_{2, j}(y)+i n R_{1, j}(y)+R_{0, j}(y)\right) z(y),
$$

where $R_{2, j}(y), R_{1, j}(y), R_{0, j}(y)$ are bounded periodic functions of the same period $\Delta_{j}=(j-1, j+1), j=0$, $\pm 1, \pm 2, z(y) \in C_{0}^{\infty}(R), z(y)=u(y)+i \vartheta(y)$.

Lemma 2.2. Let the condition i) be fulfilled. Then the operator $\left(l_{n, j}+\lambda I\right)$ considered on $C_{0}^{\infty}(R)$ is a closable operator in $L_{2}(R)$.

Proof. Let $u_{n} \in C_{0}^{\infty}(R)$ and $u_{n} \stackrel{L_{2}(R)}{\rightarrow} 0,\left(l_{n, j}+\lambda I\right) u_{n} \stackrel{L_{2}(R)}{\rightarrow} \vartheta$. If you use the operator $\left(l_{n, j}+\lambda I\right)^{*}$ formally associated with the operator $\left(l_{n, j}+\lambda I\right)$, then for arbitrary function $\omega \in C_{0}^{\infty}(R)$ 


$$
<\left(l_{n, j}+\lambda I\right) u_{n}, \omega>=<u_{n},\left(l_{n, j}+\lambda I\right)^{*} \omega>
$$

where $\left(l_{n, j}+\lambda I\right)^{*} \omega=-\omega^{\prime}+\left(i n^{3} R_{2, j}(y)-i n R_{1, j}(y)+R_{0, j}(y)\right) \vartheta=0$.

Hence

$$
<\vartheta, \omega>=<0,\left(l_{n, j}+\lambda I\right)^{*} \omega>=0
$$

Consequently, $\langle\vartheta, \omega\rangle=0$ for any $\omega \in C_{0}^{\infty}(R)$ and it means $\vartheta=0$. Lemma 2.2 is proved.

Lemma 2.3. Let the condition i) be fulfilled. Then the estimate

$$
\left\|\left(l_{n, j}+\lambda I\right) z\right\|_{2} \geq\left(\delta_{0}+\lambda\right)\|z\|_{2}
$$

holds for all $z(y) \in D\left(l_{n, j}+\lambda I\right),\|\cdot\|_{2}$ is the norm of $L_{2}(R)$.

Proof. Let $z(y) \in C_{0}^{\infty}(R)$ and $z(y)=u(y)+i \vartheta(y)$. Consider the scalar product

$$
\begin{gathered}
<\left(l_{n, j}+\lambda I\right) z, z>=\int_{-\infty}^{\infty}\left(z^{\prime}+\left(-i n^{3} R_{2, j}(y)+i n R_{1, j}(y)+R_{0, j}(y)+\lambda\right) z\right) \bar{z} d y= \\
=\int_{-\infty}^{\infty} z^{\prime}(y) z(y) d y+\int_{-\infty}^{\infty}\left(-i n^{3} R_{2, j}(y)+i n R_{1, j}(y)+R_{0, j}(y)+\lambda\right)|z|^{2} d y= \\
=i\left(\int_{-\infty}^{\infty} u \vartheta^{\prime}(y) d y+\int_{-\infty}^{\infty}\left(-i n^{3} R_{2, j}(y)+i n R_{1, j}(y)\right)|z|^{2} d y\right)+\int_{-\infty}^{\infty}\left(R_{0, j}(y)+\lambda\right)|z|^{2} d y
\end{gathered}
$$

Hence, using the properties of complex numbers, we have

$$
\left|<\left(l_{n, j}+\lambda I\right) z, z>\right| \geq\left.\left|\int_{-\infty}^{\infty}\left(R_{0, j}(y)+\lambda\right)\right| z\right|^{2} d y \mid .
$$

Since $R_{0, j}(y)$ does not change the sign, then

$$
\left|<\left(l_{n, j}+\lambda I\right) u, u>\right| \geq \int_{-\infty}^{\infty}\left|\left(R_{0, j}(y)+\lambda\right)\right||z|^{2} d y .
$$

By virtue of condition i) and using the Cauchy-Bunyakovsky inequality from the latter inequality, we have

$$
\left\|\left(l_{n, j}+\lambda I\right) z\right\|_{2} \geq\left(\delta_{0}+\lambda\right)\|z\|_{2} .
$$

Lemma 2.3 is proved.

Lemma 2.4. Let the condition i) be fulfilled.Then the operator $\left(l_{n, j}+\lambda I\right)$ has a continuous inverse operator $\left(l_{n, j}+\lambda I\right)^{-1}$ defined on the whole $L_{2}(R)$.

Proof. By the estimate (8) it suffices to show that the range is dense in $L_{2}(R)$. Let's assume that the range is not dense in $L_{2}(R)$. Then there is an element $\vartheta \in L_{2}(R)$ such that $\left\langle\left(l_{n, j}+\lambda I\right) u, \vartheta\right\rangle=0$ for all $u \in D\left(l_{n, j}\right)$. This means that

$$
\left(l_{n, j}+\lambda I\right)^{*} \vartheta=-\vartheta^{\prime}+\left(i n^{3} R_{2, j}(y)-i n R_{1, j}(y)+R_{0, j}(y)\right) \vartheta=0 .
$$

in terms of distribution theory. By the periodicity of functions $R_{0}(y), R_{1}(y), R_{2}(y)$, we have that $\left(i n^{3} R_{2, j}(y)-\right.$ $\left.-i n R_{1, j}(y)+R_{0, j}(y)\right) \vartheta \in L_{2}(R)$. From this and from (10) it follows that $\vartheta \in W_{2}^{1}(R)$, where $W_{2}^{1}(R)$ is the Sobolev space. The general theory of the embedding theorems implies that

$$
\lim _{|y| \rightarrow \infty} \vartheta(y)=0 .
$$

Now, using the equality (11) and the arguments used in the proof of the estimate (9), we obtain that

$$
\left\|\left(l_{n, j}+\lambda I\right)^{*} \vartheta\right\|_{2} \geq \delta_{0}\|\vartheta\|_{2} .
$$

From estimates (12) and (10) it follows that $\vartheta=0$. Lemma 2.4 is proved.

Let $\left\{\varphi_{j}\right\}_{j=-\infty}^{\infty} \in C_{0}^{\infty}(R)$ is a set of such functions that $\varphi_{j}(y) \geq 0, \sup p \varphi_{j} \subseteq \Delta_{j}(j \in Z), \sum_{j=-\infty}^{\infty} \varphi_{j}^{2}(y)=1$.

Here we note immediately that any point $y \in R$ can belong to no more than three segments from the system of segments $\left\{\operatorname{supp} \varphi_{j}\right\}[11,12]$. 
Assume that

$$
\begin{gathered}
K_{\lambda} f=\sum_{j=-\infty}^{\infty} \varphi_{j}(y)\left(l_{n, j}+\lambda I\right)^{-1} \varphi_{j} f, \\
B_{\lambda} f=\sum_{j=-\infty}^{\infty} \varphi_{j}^{\prime}(y)\left(l_{n, j}+\lambda I\right)^{-1} \varphi_{j} f, \quad f \in C_{0}^{\infty}(R), \quad \lambda \geq 0 .
\end{gathered}
$$

It is easy to verify that

$$
\left(l_{n}+\lambda I\right) K_{\lambda} f=f+\sum_{j} \varphi_{j}^{\prime}(y)\left(l_{n, j}+\lambda I\right)^{-1} \varphi_{j} f
$$

where

$$
\left(l_{n}+\lambda I\right) z=-z^{\prime}(y)+\left(-i n^{3} R_{2}(y)+i n R_{1}(y)+R_{0}(y)\right) z, z \in D\left(l_{n}\right) .
$$

Lemma 2.5. Let the condition i) be fulfilled. Then there is a number $\lambda_{0}>0$ such that $\left\|B_{\lambda}\right\|_{2 \rightarrow 2}<1$ for all $\lambda \geq \lambda_{0}$

Proof. Let $f \in C_{0}^{\infty}(R)$. Only functions $\varphi_{j-1}, \varphi_{j}, \varphi_{j+1}$ are nonzero in the interval $\overline{\Delta_{j}}(j \in Z)$, consequently:

$$
\left\|B_{\lambda} f\right\|_{L_{2}(R)}^{2}=\int_{-\infty}^{\infty}\left|\sum_{j=-\infty}^{\infty} \varphi_{j}^{\prime}(y)\left(l_{n, j}+\lambda I\right)^{-1} \varphi_{j} f\right|^{2} d y \leq \sum_{j=-\infty}^{\infty} \int_{\Delta_{j}}\left|\sum_{k=j-1}^{j+1}\left[\varphi_{k}^{\prime}(y)\left(l_{n, k}+\lambda I\right)^{-1} \varphi_{k} f\right]\right|^{2} d y .
$$

Hence, using the obvious inequality $(a+b+c)^{2} \leq 3\left(a^{2}+b^{2}+c^{2}\right)$ and estimate (8), we have:

$$
\begin{gathered}
\left\|B_{\lambda} f\right\|_{L_{2}(R)}^{2} \leq \sum_{j=-\infty}^{\infty} \int_{\Delta_{j}}\left|\sum_{k=j-1}^{j+1}\left[\varphi_{k}^{\prime}\left(l_{n, k}+\lambda I\right)^{-1} \varphi_{k} f\right]\right|^{2} d y \leq 9 \sum_{j=-\infty}^{\infty}\left\|\varphi_{j}^{\prime}\left(l_{n, j}+\lambda I\right)^{-1} \varphi_{j} f\right\|_{L_{2}\left(\Delta_{j}\right)}^{2} \leq \\
\leq 9 \sum_{j=-\infty}^{\infty}\left\|\varphi_{j}^{\prime}\left(l_{n, j}+\lambda I\right)^{-1} \varphi_{j} f\right\|_{L_{2}(R)}^{2} \leq 9 \cdot c \sum_{j=-\infty}^{\infty}\left\|\left(l_{n, j}+\lambda I\right)^{-1}\right\|_{L_{2}(R) \rightarrow L_{2}(R)}^{2} \cdot\left\|\varphi_{j} f\right\|_{L_{2}(R)}^{2} \leq \\
\leq \frac{9 \cdot c}{\left(\delta_{0}+\lambda\right)^{2}} \cdot \int_{-\infty}^{\infty}\left(\sum_{j} \varphi_{j}^{2}\right)|f|^{2} d y=\frac{9 \cdot c}{\left(\delta_{0}+\lambda\right)^{2}} \cdot\|f\|_{L_{2}(R)}^{2} .
\end{gathered}
$$

This implies that

$$
\left\|B_{\lambda}\right\|_{L_{2}(R) \rightarrow L_{2}(R)} \leq \frac{9 \cdot c}{\left(\delta_{0}+\lambda\right)^{2}} .
$$

From (14) it follows that it is easy to find a number $\lambda_{0}>0$, such that $\lambda \geq \lambda_{0},\left\|B_{\lambda}\right\|_{L_{2}(R) \rightarrow L_{2}(R)}<1$. Lemma 2.5 is proved.

Now consider the operator

$$
\left(l_{n}+\lambda I\right) z=z^{\prime}(y)+\left(-i n^{3} R_{2}(y)+i n R_{1}(y)+R_{0}(y)\right) z(y),
$$

where $z(y)=u(y)+i \vartheta(y), z(y) \in C_{0}^{\infty}(R),(R=(-\infty, \infty))$.

Lemma 2.6. Let the condition i) be fulfilled. Then the estimate

$$
\left\|\left(l_{n}+\lambda I\right) z\right\|_{2} \geq\left(\delta_{0}+\lambda\right)\|z\|_{2} .
$$

holds for all $z \in D\left(l_{n}\right)$. 2.6 .

Proof. We obtain the proof of Lemma 2.3 by reproducing the computations and argument used in Lemma

Lemma 2.7. Let the condition i) be fulfilled. Then the operator $l_{n}+\lambda I$ for $\lambda \geq \lambda_{0}$ is boundedly invertible and the equality

$$
\left(l_{n}+\lambda I\right)^{-1}=K_{\lambda}\left(I-B_{\lambda}\right)^{-1} .
$$

holds for the inverse operator $\left(l_{n}+\lambda I\right)^{-1}$.

The proof of Lemma 2.7 follows from the representations (13), (15) and Lemma 2.5 
3 On the existence of the resolvent. Proof of Theorem 1

Lemma 2.7 implies that

$$
u_{k}(x, y)=\sum_{n=-k}^{k}\left(l_{n}+\lambda I\right)^{-1} f_{n}(y) e^{i n x}
$$

is the solution to the problem

$$
\begin{gathered}
(L+\lambda I) u_{k}(x, y)=f_{k}(x, y), \\
u_{k}^{(i)}(-\pi, y)=u_{k}^{(i)}(\pi, y), i=0,1,2
\end{gathered}
$$

where $f_{k}(x, y) \stackrel{L_{2}(R)}{\rightarrow} f(x, y), f_{k}(x, y)=\sum_{n=-k}^{k} f_{n}(y) \cdot e^{i n x}, i^{2}=-1,\left(l_{n}+\lambda I\right)^{-1}$ is the inverse operator to the operator $l_{n}+\lambda I$. Using the inequality (3), we obtain

$$
\left\|u_{k}(x, y)\right\|_{2} \leq \frac{1}{\left(\delta_{0}+\lambda\right)}\left\|f_{k}(x, y)\right\|_{2} .
$$

Since $f_{k}(x, y) \stackrel{L_{2}(R)}{\rightarrow} f(x, y)$, then from (18) we find that

$$
\left\|u_{k}-u_{m}\right\|_{2} \leq \frac{1}{\delta_{0}}\left\|f_{k}-f_{m}\right\|_{2} \rightarrow 0, \quad k, m \rightarrow \infty .
$$

Hence, by the completeness of $L_{2}(\Omega)$, it follows that there exist a unique function $u \in L_{2}(\Omega)$ such that

$$
u_{k}(x, y) \rightarrow u(x, y) \text { as } k \rightarrow \infty .
$$

(17) and (19) imply that

$$
u(x, y)=(L+\lambda I)^{-1} f(x, y)=\sum_{n=-\infty}^{\infty}\left(l_{n}+\lambda I\right)^{-1} f_{n}(y) e^{i n x}
$$

is a strong solution for:

$$
\begin{gathered}
(L+\lambda I) u=f, \\
u^{(i)}(-\pi, y)=u^{(i)}(\pi, y), \quad i=0,1,2 .
\end{gathered}
$$

for any $f \in L_{2}(\Omega)$.

Let us recall the definition of a strong solution. The function $u \in L_{2}(\Omega)$ is called a strong solution of the problem (21)-(22), if there exists a $\left\{u_{k}\right\}_{k=1}^{\infty} \subset C_{0, \pi}^{\infty}(\Omega)$ such that

$$
\left\|u_{k}-u\right\|_{L_{2}(\Omega)} \rightarrow 0,\left\|(L+\lambda I) u_{k}-f\right\|_{L_{2}(\Omega)} \rightarrow 0 \text { as } k \rightarrow \infty .
$$

Now, it is not difficult to verify that the formula $(20)$ is the inverse operator to the closed operator $L+\lambda I$.

Lemma 2.8. [13]. Let the operator $L+\lambda_{0} I\left(\lambda_{0}>0\right)$ is boundedly invertible in $L_{2}(\Omega)$ and the estimate $\|(L+\lambda I) u\|_{L_{2}(\Omega)} \geq\|u\|_{L_{2}(\Omega)}, u \in D(L+\lambda I)$ holds for $\lambda \in\left[0, \lambda_{0}\right]$. Then the operator $L: L_{2}(\Omega) \rightarrow L_{2}(\Omega)$ is also boundedly invertible.

This and Lemma 2.1 implies that Theorem 1 holds for all $\lambda \geq 0$. Theorem 1 is completely proved.

\section{On the separability of the operator}

First, we give the lemmas that reduce the question of separability of an operator with unbounded coefficients to the case of an operator with periodic coefficients.

Lemma 2.9. Let $z(y) \in D\left(l_{n}+\lambda I\right)$ and $z(y)=u(y)+i \vartheta(y)$, then $i n^{3} R_{2}(y) z(y) \in L_{2}(R)$ if and only if $n^{3} R_{2}(y) u(y) \in L_{2}(R)$ and $n^{3} R_{2}(y) \vartheta(y) \in L_{2}(R)$.

Proof. Necessity. Let $i n^{3} R_{2}(y) z(y) \in L_{2}(R)$. Then

$$
\begin{gathered}
\left\|i n^{3} R_{2}(y) z(y)\right\|_{2}^{2}=\int_{-\infty}^{\infty}\left|i n^{3} R_{2}(y) z(y)\right|^{2} d y=\int_{-\infty}^{\infty}\left|n^{6} R_{2}^{2}(y) \| z(y)\right|^{2} d y= \\
=\int_{-\infty}^{\infty}\left|n^{6} R_{2}^{2}(y)\right|\left(|u|^{2}+|\vartheta|^{2}\right) d y=\left\|n^{3} R_{2}(y) u\right\|_{2}^{2}+\left\|n^{3} R_{2}(y) \vartheta\right\|_{2}^{2}
\end{gathered}
$$


It follows that $n^{3} R_{2}(y) u(y) \in L_{2}(R)$ and $n^{3} R_{2}(y) \vartheta(y) \in L_{2}(R)$.

Sufficiency. Let $n^{3} R_{2}(y) u(y) \in L_{2}(R)$ and $n^{3} R_{2}(y) \vartheta(y) \in L_{2}(R)$. Then

$$
\left\|i n^{3} R_{2}(y) z(y)\right\|_{2}^{2}=\left\|n^{3} R_{2}(y) u\right\|_{2}^{2}+\left\|n^{3} R_{2}(y) \vartheta\right\|_{2}^{2}
$$

Hence $i n^{3} R_{2}(y) z(y) \in L_{2}(R)$. Lemma is proved.

Remark. This Lemma is also true for $i n^{3} R_{1}(y) z(y)$.

By virtue of this Lemma, we consider the operator

$$
\left(l_{n, j}+\lambda I\right) u=u^{\prime}(y)+\left(-i n^{3} R_{2, j}(y)+i n R_{1, j}(y)+R_{0}(y)+\lambda\right) u(y),
$$

in the space $C_{0}^{\infty}(R)$ the set of infinitely differentiable, finite, and real-valued functions, where $R_{0, j}(y), R_{1, j}(y)$, $R_{2, j}(y)$ are bounded periodic coefficients of the same period $\Delta_{j}=(j-1, j+1), j= \pm 0, \pm 1, \pm 2 \ldots$

Lemma 2.10. Let the condition i) be fulfilled. Then the estimates:

$$
\left\|\left(l_{n, j}+\lambda I\right) u(y)\right\|_{2} \geq R_{0}\left(y_{j}\right)\|u\|_{2}, \quad n=0, \pm 1, \pm 2 \ldots
$$

where $R_{0}\left(y_{j}\right)=\min _{y \in \overline{\Delta_{j}}} R_{0, j}(y)$;

$$
\left\|\left(l_{n, j}+\lambda I\right) u(y)\right\|_{2} \geq|n| R_{1}\left(\overline{y_{j}}\right)\|u\|_{2}, \quad n=0, \pm 1, \pm 2 \ldots
$$

where $R_{1}\left(\overline{y_{j}}\right)=\min _{y \in \overline{\Delta_{j}}} R_{1, j}(y)$;

$$
\left\|\left(l_{n, j}+\lambda I\right) u(y)\right\|_{2} \geq|n|^{3} R_{2}\left(\overline{\overline{y_{j}}}\right)\|u\|_{2} \quad n=0, \pm 1, \pm 2 \ldots
$$

where $R_{2}\left(\overline{\overline{y_{j}}}\right)=\min _{y \in \overline{\Delta_{j}}}\left|R_{2, j}(y)\right|,\|\cdot\|_{2}$ is the norm of $L_{2}(R)$.

Proof. Let $u(y) \in C_{0}^{\infty}(R)$. Given that $\int_{-\infty}^{\infty} u^{\prime}(y) u(u) d y=0$ and reproducing the computations used in the proof of Lemma 2.1, we have:

$$
\left|<\left(l_{n, j}+\lambda I\right) u, u>\right|=\left|\int_{-\infty}^{\infty}\left(-i n^{3} R_{2, j}(y)+i n R_{1, j}(y)+R_{0, j}(y)+\lambda\right) u^{2} d y\right|
$$

From estimate (26) we find that

$$
\left|<\left(l_{n, j}+\lambda I\right) u, u>\right| \geq\left.\left|\int_{-\infty}^{\infty}\left(R_{0, j}(y)+\lambda\right)\right| u\right|^{2} d y \mid \geq \min _{y \in \overline{\Delta_{j}}} R_{0}(y)\|u\|_{2}^{2},
$$

Using the Cauchy-Bunyakovsky inequality, we obtain from (27) that

$$
\left.\| l_{n, j}+\lambda I\right) u\left\|_{2} \geq R_{0}\left(y_{j}\right)\right\| u \|_{2},
$$

where $R_{0}\left(y_{j}\right)=\min _{y \in \overline{\Delta_{j}}} R_{0}(y)$.

The proof of the inequality (28) follows from the inequality (22) of lemma 2.10.

Further, from the inequality (26) we find

$$
\left|<\left(l_{n, j}+\lambda I\right) u, u>\right| \geq\left|-i \int_{-\infty}^{\infty}\left(n^{3} R_{2, j}(y)+n R_{1, j}(y)\right) u^{2} d y\right| .
$$

Here we used the properties of complex numbers. From (29), by virtue of the condition i), we obtain the following inequalities:

$$
\begin{gathered}
\left|<\left(l_{n, j}+\lambda I\right) u, u>\right| \geq\left|\int_{-\infty}^{\infty} n R_{1, j}(y) u^{2} d y\right| \geq|n| R_{1}\left(\overline{y_{j}}\right)\|u\|_{2}^{2}, \\
\left|<\left(l_{n, j}+\lambda I\right) u, u>\right| \geq\left.\left.\left|\int_{-\infty}^{\infty}\left(-n^{3} R_{2, j}(y)\right)\right| u\right|^{2} d y|\geq| n\right|^{3}\left|R_{2}\left(\overline{\overline{y_{j}}}\right)\right|\|u\|_{2}^{2},
\end{gathered}
$$

where $R_{1}\left(\overline{y_{j}}\right)=\min _{y \in \overline{\Delta_{j}}} R_{1, j}(y), R_{2}\left(\overline{\overline{y_{j}}}\right)=\min _{y \in \overline{\Delta_{j}}}\left|R_{2, j}(y)\right|$. From these inequalities and using the Cauchy-Bunyakovsky inequality, we find that:

Lemma 2.10 is proved.

$$
\begin{gathered}
\left.\| l_{n, j}+\lambda I\right) u\left\|_{2} \geq|n| R_{1}\left(\overline{y_{j}}\right)\right\| u \|_{2} ; \\
\left.\| l_{n, j}+\lambda I\right) u\left\|_{2} \geq n^{3}\left|R_{2}\left(\overline{\overline{y_{j}}}\right)\right|\right\| u \|_{2} .
\end{gathered}
$$


Lemma 2.11. Let the condition i) be fulfilled and $\lambda \geq \lambda_{0}, \alpha=0,1,2,3, p(y)$ defined on $R$ continuous function. Then the estimate

$$
\left\|p(y)|n|^{\alpha}\left(l_{n}+\lambda I\right)^{-1}\right\|_{L_{2}(R) \rightarrow L_{2}(R)}^{2} \leq c(\lambda) \sup _{j \in Z}\left\|p(y)|n|^{\alpha} \varphi_{j}\left(l_{n, j}+\lambda I\right)^{-1}\right\|_{L_{2}\left(\Delta_{j}\right) \rightarrow L_{2}\left(\Delta_{j}\right)}^{2} .
$$

Proof. Let $f \in C_{0}^{\infty}(R)$. From the representation (16), taking the properties of the functions $\varphi_{j}(j \in Z)$ into account, we have:

$$
\begin{gathered}
\left\|p(y)|n|^{\alpha}\left(l_{n}+\lambda I\right)^{-1} f\right\|_{L_{2}(R)}^{2}=\left\|p(y)|n|^{\alpha} K_{\lambda}\left(I-B_{\lambda}\right)^{-1} f\right\|_{L_{2}(R)}^{2}= \\
=\left.\left.\int_{-\infty}^{\infty}|p(y)| n\right|^{\alpha} \sum_{\{j\}} \varphi_{j}\left(l_{n, j}+\lambda I\right)^{-1} \varphi_{j}\left(I-B_{\lambda}\right)^{-1} f\right|^{2} d y
\end{gathered}
$$

As it is known that on $\Delta_{j}(j \in Z)$ the interval only functions $\varphi_{j-1}, \varphi_{j}, \varphi_{j+1}$ are nonzero, therefore

$$
\begin{gathered}
\left\|p(y)|n|^{\alpha}\left(l_{n}+\lambda I\right)^{-1} f\right\|_{L_{2}(R)}^{2} \leq\left.\left.\sum_{j=-\infty}^{\infty} \int_{\Delta_{j}}|p(y)| n\right|^{\alpha} \sum_{j-1}^{j+1} \varphi_{j}\left(l_{n, j}+\lambda I\right)^{-1} \varphi_{j}\left(I-B_{\lambda}\right)^{-1} f\right|^{2} d y \leq \\
\leq 9 \sum_{j=-\infty}^{\infty}\left\|\left.|p(y)| n\right|^{\alpha} \varphi_{j}\left(l_{n, j}+\lambda I\right)^{-1} \varphi_{j}\left(I-B_{\lambda}\right)^{-1} f\right\|_{L_{2}\left(\Delta_{j}\right)}^{2} \leq \\
\leq 9 \sup _{j \in Z}\left\|p(y)|n|^{\alpha} \varphi_{j}\left(l_{n, j}+\lambda I\right)^{-1}\right\|_{L_{2}\left(\Delta_{j}\right)}^{2} \cdot \sum_{j=-\infty}^{\infty} \int_{\Delta_{j}}\left|\varphi_{j}\left(I-B_{\lambda}\right)^{-1} f\right|^{2} d y \leq \\
\leq 9 \sup _{j \in Z}\left\|p(y)|n|^{\alpha} \varphi_{j}\left(l_{n, j}+\lambda I\right)^{-1}\right\|_{L_{2}\left(\Delta_{j}\right)}^{2} \cdot \int_{-\infty}^{\infty}\left(\sum_{j} \varphi_{j}^{2}\right)\left|\left(I-B_{\lambda}\right)^{-1} f\right|^{2} d y
\end{gathered}
$$

Since $\left(\sum_{j} \varphi_{j}^{2}\right)=1$, then from (31) we have

$$
\begin{gathered}
\left\|p(y)|n|^{\alpha}\left(l_{n}+\lambda I\right)^{-1} f\right\|_{L_{2}(R)}^{2} \leq 9 \sup _{j \in Z}\left\|p(y)|n|^{\alpha} \varphi_{j}\left(l_{n, j}+\lambda I\right)^{-1}\right\|_{L_{2}\left(\Delta_{j}\right)}^{2} \cdot \int_{-\infty}^{\infty}\left|\left(I-B_{\lambda}\right)^{-1} f\right|^{2} d y \leq \\
\leq 9 \sup _{j \in Z}\left\|p(y)|n|^{\alpha} \varphi_{j}\left(l_{n, j}+\lambda I\right)^{-1}\right\|_{L_{2}\left(\Delta_{j}\right)}^{2} \cdot\left\|\left(I-B_{\lambda}\right)^{-1}\right\|_{2 \rightarrow 2}^{2} \cdot\|f\|_{2}^{2} .
\end{gathered}
$$

Lemma 2.5 implies that $\left\|I-B_{\lambda}\right\|_{2 \rightarrow 2}^{2}<c(\lambda)$. From this and from (32) we obtain that

$$
\left.\| p(y)|n|^{\alpha}\right]\left(l_{n, j}+\lambda I\right)^{-1}\left\|_{L_{2}(R) \rightarrow L_{2}(R)} \leq 9 \cdot c(\lambda) \sup _{j \in Z}\right\| p(y)|n|^{\alpha} \varphi_{j}\left(l_{n, j}+\lambda I\right)^{-1} \|_{L_{2}\left(\Delta_{j}\right)}^{2} .
$$

Lemma 2.11 is proved.

Lemma 2.12. Let the conditions i)-ii) be fulfilled. Then the following estimates:

$$
\begin{gathered}
\left\|R_{0}(y)\left(l_{n}+\lambda I\right)_{-1}\right\|_{L_{2}(R) \rightarrow L_{2}(R)} \leq C_{0}<\infty ; \\
\left\|R_{1}(y)|n|\left(l_{n}+\lambda I\right)_{-1}\right\|_{L_{2}(R) \rightarrow L_{2}(R)} \leq C_{1}<\infty ; \\
\left\|R_{2}(y)|n|^{3}\left(l_{n}+\lambda I\right)_{-1}\right\|_{L_{2}(R) \rightarrow L_{2}(R)} \leq C_{2}<\infty ;
\end{gathered}
$$

hold, where $C_{0}, C_{1}, C_{1}$ are independent of $n(n=0, \pm 1, \pm 2 \ldots)$.

Proof. (30) shows that the operator $R_{0}\left(l_{n}+\lambda I\right)$ is bounded, if $\sup _{j \in Z}\left\|R_{0}(y) \varphi_{j}\left(l_{n, j}+\lambda I\right)^{-1}\right\|_{L_{2}\left(\Delta_{j}\right)}$ is bounded. Therefore, we will estimate the last expression

$$
\begin{gathered}
\left\|R_{0}(y) \varphi_{j}\left(l_{n}+\lambda I\right)^{-1}\right\|_{L_{2}(R) \rightarrow L_{2}(R)}^{2} \leq C(\lambda) \sup _{j \in Z}\left\|R_{0}(y) \varphi_{j}\left(l_{n, j}+\lambda I\right)^{-1}\right\|_{L_{2}\left(\Delta_{j}\right)}^{2} \leq \\
\leq C(\lambda) \sup _{j \in Z} \max _{y \in \Delta_{j}}\left|R_{0}(y) \varphi_{j}\right|^{2}\left\|\left(l_{n, j}+\lambda I\right)^{-1}\right\|_{L_{2}\left(\Delta_{j}\right)}^{2} \leq C(\lambda) \sup _{j \in Z} \max _{y \in \Delta_{j}} R_{0}^{2}(y)\left\|\left(l_{n, j}+\lambda I\right)^{-1}\right\|_{L_{2}\left(\Delta_{j}\right)}^{2} .
\end{gathered}
$$


Hence, taking the inequality (23) and the condition ii) into account, we find that

$$
\left\|R_{0}(y)\left(l_{n}+\lambda I\right)^{-1}\right\|_{L_{2}(R) \rightarrow L_{2}(R)}^{2} \leq C(\lambda) \sup _{|y-t| \leq 1} \frac{R_{0}^{2}(y)}{R_{0}^{2}(t)}<C(\lambda) \cdot \mu_{0}^{2} \leq C_{0}^{2}<\infty .
$$

The last estimate proves the inequality (33) of Lemma 2.12 .

Let us prove the inequality (34). Using Lemma 2.11, we have:

$$
\begin{gathered}
\left\|R_{1}(y)|n|\left(l_{n}+\lambda I\right)^{-1}\right\|_{L_{2}(R) \rightarrow L_{2}(R)}^{2} \leq C(\lambda) \sup _{j \in Z}\left\|R_{1}(y)|n| \varphi_{j}\left(l_{n, j}+\lambda I\right)^{-1}\right\|_{L_{2}\left(\Delta_{j}\right) \rightarrow L_{2}\left(\Delta_{j}\right)}^{2} \leq \\
\leq C(\lambda) \sup _{j \in Z} \max _{y \in \overline{\Delta_{j}}} R_{1}^{2}(y)|n|^{2}\left\|\left(l_{n, j}+\lambda I\right)^{-1}\right\|_{L_{2}\left(\Delta_{j}\right) \rightarrow L_{2}\left(\Delta_{j}\right)}^{2} .
\end{gathered}
$$

Hence, using (24), as well as considering condition ii), we find that

$$
\left\|R_{1}(y)|n|\left(l_{n}+\lambda I\right)^{-1}\right\|_{L_{2}(R) \rightarrow L_{2}(R)}^{2} \leq C(\lambda) \cdot \mu_{1}^{2} \leq C_{1}^{2}<\infty .
$$

The inequality (34) is proved.

Let us prove the inequality (35). Reproducing the computations arguments used in the proof of the inequalities (33), (34) and using the inequality (25), we obtain

$$
\begin{gathered}
\left\|R_{2}(y)|n|^{3}\left(l_{n}+\lambda I\right)^{-1}\right\|_{L_{2}(R) \rightarrow L_{2}(R)}^{2} \leq C(\lambda) \sup _{j \in Z}\left\|R_{2}(y)|n|^{3} \varphi_{j}\left(l_{n, j}+\lambda I\right)^{-1}\right\|_{L_{2}\left(\Delta_{j}\right) \rightarrow L_{2}\left(\Delta_{j}\right)}^{2} \leq \\
\leq C(\lambda) \cdot \mu_{2}^{2} \leq C_{2}^{2}<\infty .
\end{gathered}
$$

The inequality (35) is proved. Lemma 2.12 is completely proved.

\section{Proof of Theorem 2}

The representation (20) implies that

$$
R_{0}(y) u(x, y)=R_{0}(y)(L+\lambda I)^{-1} f(x, y)=\sum_{n=-\infty}^{\infty} R_{0}(y)\left(l_{n}+\lambda I\right)^{-1} f_{n}(y) \cdot e^{i n x} .
$$

Calculate the norm $R_{0}(y)(L+\lambda I)^{-1} f$ :

$$
\begin{gathered}
\left\|R_{0}(y)(L+\lambda I)^{-1} f\right\|_{L_{2}(\Omega)}^{2}=\left\|\sum_{n=-\infty}^{\infty} R_{0}(y)\left(l_{n}+\lambda I\right)^{-1} f_{n}(y) \cdot e^{i n x}\right\|_{L_{2}(\Omega)}^{2} \leq \\
\leq 2 \pi \sum_{n=-\infty}^{\infty}\left\|R_{0}(y)\left(l_{n}+\lambda I\right)^{-1} f_{n}(y) \cdot e^{i n x}\right\|_{L_{2}(\Omega)}^{2} .
\end{gathered}
$$

From this and from Lemma 2.12 we have that

$$
\left\|R_{0}(y)(L+\lambda I)^{-1} f\right\|_{L_{2}(\Omega)}^{2} \leq 2 \pi \sum_{n=-\infty}^{\infty}\left\|R_{0}(y)\left(l_{n}+\lambda I\right)^{-1}\right\|_{L_{2}(\Omega)}^{2} \cdot\left\|f_{n}(y)\right\|_{L_{2}(\Omega)}^{2} \leq C_{0}^{2}\|f\|_{L_{2}(\Omega)}^{2} .
$$

From the last estimate, it follows that

$$
\left\|R_{0}(y) u(x, y)\right\|_{L_{2}(\Omega)}=\left\|R_{0}(y)(L+\lambda I)^{-1} f(x, y)\right\|_{L_{2}(\Omega)} \leq C_{0}\left\|(L+\lambda I)^{-1} u\right\|_{L_{2}(\Omega)}
$$

where $(L+\lambda I) u=f$.

Similarly, by virtue of the estimate (34) we have:

$$
\left\|R_{1}(y) \frac{\partial u}{\partial x}\right\|_{L_{2}(\Omega)} \leq C_{1}\left\|(L+\lambda I)^{-1} u\right\|_{L_{2}(\Omega)} .
$$


Similarly, repeating the above calculations, we get that

$$
\left\|R_{1}(y) \frac{\partial^{3} u}{\partial x^{3}}\right\|_{L_{2}(\Omega)}^{2} \leq C_{2}\left\|(L+\lambda I)^{-1} u\right\|_{L_{2}(\Omega)} .
$$

Now the inequalities (36)-(38) imply that

$$
\begin{gathered}
\left\|\frac{\partial u}{\partial y}\right\|_{L_{2}(\Omega)}=\left\|(L+\lambda I)-R_{2}(y) \frac{\partial^{3} u}{\partial x^{3}}-R_{1}(y) \frac{\partial u}{\partial y}-R_{0}(y) u-\lambda u\right\|_{L_{2}(\Omega)} \leq\|(L+\lambda I)\|_{L_{2}(\Omega)}+ \\
+\left\|R_{2}(y) \frac{\partial^{3} u}{\partial x^{3}}\right\|_{L_{2}(\Omega)}+\left\|R_{1}(y) \frac{\partial u}{\partial y}\right\|_{L_{2}(\Omega)}+\left\|R_{0}(y) u\right\|_{L_{2}(\Omega)}+\|\lambda u\|_{L_{2}(\Omega)} \leq\|(L+\lambda I) u\|_{L_{2}(\Omega)}+ \\
+C_{2}\|(L+\lambda I) u\|_{L_{2}(\Omega)}+C_{1}\|(L+\lambda I) u\|_{L_{2}(\Omega)}+C_{0}\|(L+\lambda I) u\|_{L_{2}(\Omega)}+\lambda\|(L+\lambda I) u\|_{L_{2}(\Omega)} \leq \\
\leq C(\lambda)\|(L+\lambda I) u\|_{L_{2}(\Omega)} .
\end{gathered}
$$

We obtain from the inequalities (36)-(39) that

$$
\left\|\frac{\partial u}{\partial y}\right\|_{L_{2}(\Omega)}+\left\|R_{2}(y) \frac{\partial^{3} u}{\partial x^{3}}\right\|_{L_{2}(\Omega)}+\left\|R_{1}(y) \frac{\partial u}{\partial y}\right\|_{L_{2}(\Omega)}+\left\|R_{0}(y) u\right\|_{L_{2}(\Omega)} \leq C(\lambda)\left(\|L u\|_{L_{2}(\Omega)}+\|u\|_{L_{2}(\Omega)}\right) .
$$

Theorem 2 is completely proved.

\section{References}

1 Temam R. Sur un probleme non linearie / R. Temam // Math. Pures. Apple. - 1969. - 48. - № 2. P. 159-172.

2 Лионс Ж.Л. Некоторые методы решения нелинейных краевых задач / Ж.Л. Лионс. - М.: Мир, 1972. $-586 \mathrm{c}$.

3 Дубинский Ю.А. Об одной абстрактной теореме и ее приложения к краевым задачам для неклассических уравнений / Ю.А.Дубинский // Матем. сб. - 1969. - 79(121). - № 1. - С. 91-117.

4 Юрчук Н.И. О граничных задачах для уравнений, содержащихся в главной части оператор вида $d^{2 m+1} / d t^{2 m+1} /$ Н.И. Юрчук // Дифференциальные уравнения. - 1974. - 10. - № 4. - С. 759-762.

5 Пятков С.Г. Об одном линейном уравнении неклассического типа высокого порядка / С.Г. Пятков // Препринт им. СО АН СССР. - 1981. - 24 с.

6 Bona J.Y. A nonhomogeneous boundary-value problem for the Korteweg-de Vries equation posed on a finite domain / J.Y. Bona, Shu Ming Sun, Bing-Yu Zhang // Comm. Partial Differential Equations. 2003. - 28. - №7-8. - P. 1391-1436.

7 Бубнов В.А. Разрешимость в целом нелинейных граничных задач для уравнения Кортевега-де Фриза в ограниченной области / В.А. Бубнов // Дифференциальные уравнения. $-1980 .-16 .-$ № 1 . - C. $34-41$.

8 Похожаев С.И. О некоторых весовых тождествах для решений обобщенных уравнений Кортевега-де Фриза / С.И.Похожаев // Математические заметки. - 2011. - 89. - Вып. 3. - С. 393-409.

9 Муратбеков М.Б. О существовании и аппроксимативных свойствах решений полупериодической задачи Дирихле для одного класса нелинейных вырождающихся уравнений неклассического типа / М.Б. Муратбеков, Г.К. Рахимова, А.Б. Шыракбаев // Матем. журн. - 2011. - 13. - № 2 (48). C. $95-109$.

10 Тихонов А.Н. Уравнения математической физики / А.Н. Тихонов, А.А. Самарский. - М.: Наука, 1972. $-735 \mathrm{c}$.

11 Отелбаев М. Коэрцитивные оценки и теоремы разделимости для эллиптических уравнений в $R^{n} /$ М. Отелбаев // Тр. Матем. ин-та АН СССР. - 1983. - 161. - С. 195-217.

12 Muratbekov M. On the existence of a resolvent and separability for a class of singular hyperbolic type differential operators on an unbounded domain / M. Muratbekov, M. Otelbaev // Eurasian mathematical journal. - 2016. - 7. - No I. - P. 50-67. 
13 Ахиезер Н.И. Теория линейных операторов в гильбертовом пространстве / Н.И. Ахиезер, И.М. Глазман. - М.: Наука, 1966. - 644 с.

М.Б. Муратбеков, А.О. Сулеймбекова

\title{
Кортевег-де Фриз типті сызықты сингулярлы операторлардың бір класының бар болуы және бөліктенуі туралы
}

\author{
Мақалада шексіз облыста коэффициенттері шексіздікте жылдам өсетін Кортвег-де Фриза типті сыз- \\ ықты оператор зерттелген. Жоғарыдағы көрсетілген дифференциалдық оператор үшін төмендегі \\ сұрақтар қарастырылған: \\ - резольвентаның бар болуы; \\ - оператордың бөліктенуі, яғни оператордың анықталу облысындағы функциялардың тегістігі зерт- \\ телген.
}

Kiлm сөздер: резольвента, Коревег-де Фриз типті сингулярлы оператор, бөліктену.

М.Б. Муратбеков, А.О. Сулеймбекова

\section{О существовании резольвенты и разделимости одного класса линейных сингулярных операторов типа Кортевега-де Фриза}

\author{
В статье исследован линейный дифференциальный оператор типа Кортевега-де Фриза в случае не- \\ ограниченной области с сильно растущими коэффициентами на бесконечности. Для указанного выше \\ оператора изучены следующие вопросы: \\ - существование резольвенты; \\ - разделимость оператора, т.е. гладкость функций из области определения изучаемого оператора. \\ Ключевые слова: резольвента, сингулярный оператор типа Кортевега-де Фриза, разделимость.
}

\section{References}

1 Temam, R. (1969). Sur un probleme non linearie. J. Math.Pures. Apple, 48(2), 159-172.

2 Lyons, J.L. (1972). Nekotorye metody resheniia nelineinykh kraevykh zadach /Some methods for solving nonlinear boundary value problems]. Moscow: Mir [in Russian].

3 Dubinsky, Yu.A. (1969). Ob odnoi abstraktnoi teorii i ee prilozheniiakh k kraievym zadacham dlia neklassicheskikh uravnenii [On an abstract theorem and its applications to boundary value problems for nonclassical equations]. Matematicheskii sbornik - Mathematical collection, 79(121), 1, 91-117 [in Russian].

4 Yurchuk, N.I. (1974). O hranichnykh zadachakh dlia uravnenii, soderzhashchikh v hlavnoi chasti operator vida $d^{2 m+1} / d t^{2 m+1}$ [On boundary value problems for equations containing operators of the form $d^{2 m+1}$ $/ d t^{2 m+1}$ in the main part]. Differentsialnye uravneniia - Differential equation., 10(4), $759-762$ [in Russian].

5 Pyatkov, S.G. (1981). Ob odnom lineinom uravnenii neklassicheskoho tipa vysokoho poriadka [On a non-classical type high-order linear equation]. Preprint imeni SO AN SSSR - Preprint of Institute of Mathematics, Siberian Branch of the USSR Academy of Sciences, 24 [in Russian].

6 Bona, J.Y., Shu Ming Sun, \& Bing-Yu Zhang (2003). A nonhomogeneous boundary-value problem for the Korteweg-de Vries equation posed on a finite domain. Comm. Partial Differential Equations., 28(7-8), 1391-1436. 
7 Bubnov, B.A. (1979). Razreshimost v tselom nelineinykh hranichnykh zadach dlia uravneniia Kortevehade Friza v ohranichennoi oblasti [Solvability in the large of nonlinear boundary value problems for the Korteweg-de Vries equation in a bounded domain]. Differentsialnye uravneniia - Differential equation, 16(1), 34-41 [in Russian].

8 Pokhozhaev, S.I. (2011). O nekotorykh vesovykh tozhdestvakh dlia reshenii obobshchennykh uravnenii Korteveha-de Friza [Weighted identities for solutions of generalized Korteweg-de Vries equations]. Matematicheskiie zametki - Math. Notes, 89(3), 393-409 [in Russian].

9 Muratbekov, M.B., Rakhimova, G.K., \& Shyrakbaev, A.B. (2011). O sushchestvovanii i approksimativnykh svoistvakh reshenii poluperiodicheskoi zadachi Dirikhle dlia odnoho klassa nelineinykh vyrozhdaiushchikhsia uravnenii neklassicheskoho tipa [On the existence and approximation properties of solutions of the semi-periodic Dirichlet problem for a class of nonlinear degenerate non-classical equations]. Matematicheskii zhurnal - Math journal, 13, 2(48), 95-109 [in Russian].

10 Tikhonov, A.N., \& Samarskii, A.A. (1972). Uravneniia matematicheskoi fiziki [Equations of mathematical physics]. Moscow: Nauka [in Russian].

11 Otelbaev, M. (1983). Koertsitivnye otsenki i teoremy razdelimosti dlia ellipticheskikh uravnenii v $R^{n}$ [Coercive estimates and separability theorems for elliptic equations in $R^{n}$. Trudy Matematicheskoho instituta AN SSSR - Proceedings of the Mathematical Institute of the USSR Academy of Sciences, 161, 195-217 [in Russian].

12 Muratbekov, M., \& Otelbaev, M. (2016). On the existence of a resolvent and separability for a class of singular hyperbolic type differential operators on an unbounded domain. Eurasian mathematical journal, 7(1), 50-67.

13 Akhiezer, N.I., \& Glazman, I.M. (1966). Teoriia lineinykh operatorov v hilbertovom prostranstve [Theory of linear operators in Hilbert space]. Moscow: Nauka [in Russian]. 